\title{
CuAndo la filología SE HACE enSAYO
}

\author{
Juan Carlos Ara Torralba \\ (Universidad de Zaragoza)
}

\section{Cuestión de actitud}

No hay lugar para milagrosas epifanías: el estudio filológico se hace ensayo solo cuando existe una voluntad decidida de ensayar, de practicar una escritura desatada de determinadas convenciones genéricas propias del estudio académico. Es por tanto cuestión de grado y de designio personal la tarea de entender a la literatura y su historia como materia ensayable. De grado literario, pues un tratado pasa a ser ensayo cuando aumenta el énfasis en los tres clásicos modos del arte persuasorio (definidos por Aristóteles), el ethos, el pathos y el logos. Y de propósito o providencia, porque el autor persigue una consciente forma de dominio de la materia bien diferente de la académica.

Así, casi toda la amplia bibliografía que explica el nacimiento y desarrollo del ensayo como género esencialmente ligado al yo emisor habría de ser situada, en la práctica, en el ámbito del ethos. Frente a la monografía académica, uno de cuyos méritos parece residir en la fría impersonalidad del discurso, el ensayo filológico participa de la expansión emotiva propia de otros géneros literarios primarios; esta metástasis del yo pretende certificar, entre otras cosas, la credibilidad y autenticidad de lo escrito en cuanto punto de vista autorizado y en cuanto instancia de principio moral; al cabo proviene en derechura de aquellas una suerte de pacto ensayístico que aceptan emisor y receptor y que convierten al ensayo (no sólo el filológico) en texto conversado, en lugar cercano, cálido, cordial, y propenso al comentario. Para que esa conversación sea efectiva, la materia filológica ensayable ha de ser compartida con el lector o 
a lo menos suscitar su curiosidad. Necesariamente tiene que existir una emoción, consenso o sentir común (pathos) para que la Filología se haga Ensayo y no se limite a mera arqueología, más propia de las monografías académicas, poco propicias, en verdad, al entusiasmo y la vehemencia. Los buenos ensayos filológicos acertaron en tratar temas palpitantes, bien por coyuntura histórica, bien por navegar por autores clásicos cuya vigencia viene dada de sí por el propio calificativo.

Muestra también el ensayo filológico, en cuanto más libre y desatado, en cuanto personal y conversado, un argumentario persuasivo seductor, un discurso donde razonar (logos). El ensayista echa mano de cuantos instrumentos le ofrecen las artes del discurso para lograr ese grado literario superior que le aleja del estilo humilde (pero en ocasiones un sí es no es soberbio) y la estructura encorsetada, convencional, de los tratados filológicos. De la invención acertada del tema (antes señalada) se derivan una disposición y elocución de los argumentos que no rehúyen otros estilos ni, y esto es muy revelador, el despliegue de evidencias casi a modo de novelas ${ }^{1} \mathrm{o}$ al menos de discursos estructurados de manera envolvente, climática, en ningún caso monológicos.

De vuelta a la primordial voluntad de ensayar, conviene decir que todo ensayo filológico, en cuanto avance y reflexión cultural, suele ir más allá de lo literario. Tiene, claro es, su campo o territorio simbólico de origen, que no es otro que el de la literatura, sus temas, autores e historia (sus tramas, libros, nombres), pero el ensayo filológico no solo ha de discurrir por ese campo sino imponer su dominio; dicho de otro modo, el ensayista tiene que demostrar su capacidad y poder sobre él, su auctoritas, ese valer que proviene de una sólida sabiduría y que le permite emitir opiniones cualificadas valorables por el lector. En este sentido, el de la aceptación por el lector de una voz personal con gran capacidad moral (ética, también patética), el ensayo filológico se homologa al intelectual. En realidad, es intelectual. Y en tanto que intelectual su dominio no se ejerce por la vara erudita, sino por la persuasión (repetimos: ética y patética) mediante la fortaleza de una voz cercana que no solo formula certezas, sino que también insinúa dudas y siempre entrega razones. De hecho, si el ensayo es, desde su origen, aproximación, prueba, difícilmente puede hablarse en puridad de aproximación erudita, salvo que se acepte, en cierto modo, un oxímoron. La erudición del ensayista se supone en cuanto dominio, pero no se ostenta ni es la clave de la altura de la composición de un texto que avanza por relaciones interpretativas 
seductoras; su notación es necesaria, en todo caso, en las monografías académicas, donde el valor de lo heurístico, de la suma positiva de datos, sí es esa clave, de tono menor, grave, que sirve de punto de referencia para la construcción de los apartados canónicos propios de un buen tratado académico. La altura especulativa es condición indispensable del ensayo filológico, y de ella provienen tanto la predilección por la ágil y variada exposición de argumentos —en lugar de obstinadas expoliciones de una tesis-, como la natural búsqueda de síntesis estimulantes.

\section{Voluntad de escuela}

De ahí que el pensar por desarrollo de programa y puntos, tan propio del siglo XIX, y que conducía indefectiblemente al tratadismo erudito, no fuera territorio propicio para el nacimiento y progreso del ensayo filológico. Harto complicado es encajar la labor de Marcelino Menéndez Pelayo en este género que transita, sí, por territorios genéricos secundarios, pero que hubo de aspirar a hacerlo por dominios primarios aledaños a los del campo literario tout court. Por moderno y atrevido, presto y generoso, liberal en parecido sentido que dio Lope al amor en su célebre soneto, el ensayo filológico en España nace cuando confluyeron las condiciones de emancipación y culto del sujeto que hemos sugerido más arriba al meditar acerca de la metástasis del yo y sus implicaciones éticas². Su fundación, en cuanto hábito literario, solo fue posible cuando la evolución de la cultura y del campo literario de fines del siglo XIX y principios del XX también dieron lugar a revoluciones de fuste en la novela, lírica y dramaturgia favorecidas por la afirmación del yo (y los innumerables problemas derivados de su lugar exacto en la enunciación de lo percibido como literario), al uso del culte du moi barresiano, y, no lo olvidemos de ninguna manera, por el condicente y contemporáneo nacimiento del intelectual siempre a la búsqueda de ampliar el horizonte del público lector. Solo entonces comenzaron a urdirse los mimbres para el tejido de una especie de protocolo modernista, liberal e intelectual que terminó por caracterizar al ensayo y, claro es, a su subgénero filológico.

Por tales razones, leer determinados textos de Ramón Menéndez Pidal sin tener en cuenta los ensayos contemporáneos del Unamuno de la Vida de don Quijote y Sancho (1905), o del Azorín de La ruta de don Quijote (1905), Lecturas españolas (1912), Clásicos y modernos (1913) y Los valores literarios (1914), es olvidar la impronta de un yo preocupado por la voluntad de alcanzar y modelar pedagógicamente un público lector, todavía muy restringido, concernido en

«La moderna prosa ensayística nace con el modernismo» (Gracia y Ródenas 2015a:81). 
la tarea moral de regenerar la cultura nacional desde presupuestos decididamente nacionalistas. Cierto es que los primeros trabajos de Ramón Menédez Pidal nacen de la necesidad de implantar en España modelos y metodología germánicas de lingüística histórica comparada (El Poema del Cid —1908_, edición de la Primera Crónica General —1905— para la Nueva Biblioteca de Autores Españoles...) y que se ahormaron en moldes genéricos académicos (disciplinados, aunque lejanos de la retórica tratadista decimonónica), pero no lo fue menos que esa actividad sería fundamental para señalar, como objetos de materia ensayable común, a muy determinados libros y momentos fundacionales de nuestra historia nacional de la literatura. El mismo Menéndez Pidal hubo de escribir, años más tarde, verdaderos ensayos filológicos ideados desde el designio de sintetizar los datos referidos a aquellos libros y épocas en textos de hilo argumentativo tan robusto - como claro y sencillo su estilo- y persuasivo que han conseguido que, en tanto que ensayos, conserven una vigencia, diríamos, clásica. Poca arqueología encontrará el lector actual en dichos ensayos, sean Poesía juglaresca y juglares (1924), Orígenes del español (1926) o, sobre todo, La España del Cid (1929).

Ramón Menéndez Pidal, en estos sentidos, fue modelo, maestro y fundador. En sus afanes en la preparación y establecimiento de la Junta para la Ampliación de Estudios, de la del Centro de Estudios Históricos en 1910 y sobre todo de la Sección de Filología Española de este último, encontramos el origen de la bien Ilamada «Escuela de Filología Española», cantera de la que surgirán los mejores ensayistas del campo en las dos décadas subsiguientes al nacimiento de la Revista de Filología Española en 1914. Instalados los pilares, sobrevendrían los años de «la construcción de una tradición literaria nacional» (Pozuelo Yvancos 2011:547) a cuya tarea la redacción y difusión de buenos ensayos filológicos tanto hubo de contribuir.

Y para aquellas aspiraciones resultaron primordiales tanto la ampliación del público lector implícito interesado en temas literarios como la mayor preparación cultural del mismo en aras de poder convertirse en partícipe ideal de las meditaciones ensayísticas de base filológica. Se difundieron los avances de la filología de la escuela a través de los clásicos de La Lectura, de los Anejos de la Revista de Filología Española o de los «Clásicos Castellanos» de Espasa-Calpe, y desde los trabajos de Ramón Menéndez Pidal, según anotamos, y de sus discípulos (de Tomás Navarro Tomás a Federico de Onís, de Antonio García Solalinde y José Fernández Montesinos a Américo Castro), se acotaron autores, libros y épocas susceptibles de convertirse en necesaria 
materia ensayable, en temas de palpitante vigencia por aquellas sazones cuando gravitaba un pathos común de modernidad y nacionalismo.

A ello se aplicó con denuedo Américo Castro, uno de los pioneros filólogos del Centro de Estudios Históricos desde su ingreso en 1910 y discípulo directo de Ramón Menéndez Pidal. Partiendo de una sólida formación recibida de aquel, Castro mantuvo durante toda su larga trayectoria intelectual una vocación de ensayar acerca de temas aquende los orígenes del español y su literatura medieval. Señaló como materia autores y temas de los siglos de Oro (tal como lo estaban haciendo, directa o indirectamente, año arriba, año abajo, Ortega con sus Meditaciones del Quijote -1914_, Salvador de Madariaga con su Guía del lector del Quijote -1926-, Ramiro de Maeztu con Don Quijote, Don Juan y la Celestina -1926- o Manuel Azaña con La invención del Quijote y otros ensayos -1934-) en libros ineludibles como la Vida de Lope de Vega (1919, junto a H.A. Rennert), El pensamiento de Cervantes (1925), Teresa la Santa y otros ensayos (1929), España en su historia: cristianos, moros y judíos (1948), La realidad histórica de España (1954) o Cervantes y los casticismos españoles (1966). También Castro terminó de moldear el género del ensayo filológico, no solo por la búsqueda de materias reveladoras de algo más que la propia literatura, sino por la escritura de persuasión obstinada $-\mathrm{y}$ no exenta de desafío del heterodoxo consciente al lector polemista- y por la ampliación del campo de estudio al contexto y tradiciones históricas de campos afines internacionales.

En los años veinte y treinta del siglo XX la literatura y el ensayo ya no solo fueron modernos, sino también modernist, y el afianzamiento de esta actitud alcanzó, asimismo, a los ensayos filológicos. Queremos decir que al fin el ensayo filológico fue alcanzando niveles homólogos a los de los países más avanzados de la cultura occidental de la mano de los jóvenes preparados en el círculo de la Revista de Filología Española. Muchos de ellos fueron, además, escritores, poetas los más, por lo que no solo eran poetas doctos en materia filológica (ediciones de clásicos en su ejecutoria, tesis de mérito bajo la tutela de los Castro o Pidal...) sino también lectores atentos a novedades españolas (Ortega siempre en la mesa de textos por leer) y europeas (la Revista de Occidente como vademécum generacional, tal como demuestra la Mentira desnuda (Hitos), aquella recopilación modernist de ensayos de Antonio Marichalar), además de escritores diestros en los modos literarios por los cuales el artículo académico, la monografía o el estudio podían devenir en ensayos según el manejo hábil de la voz enunciadora, la elección de un tono 
sutilmente atildado, pulcro y, por qué no, el despliegue selecto, meditado, del arsenal de figuras ofrecidas para la elocutio retórica. Y a todo ello sumaron otra novedad esencial: la apropiación de la literatura contemporánea como materia ensayable — en muchas ocasiones en breves pero brillantes artículos publicados en revistas, luego compilados en volumen-. Así, Ángel Valbuena Prat, especialista en los autos sacramentales de Calderón, publicó, años antes de su Historia de la literatura española (1937), el libro La poesía española contemporánea (1930); Pedro Salinas, catedrático de Literatura y que se había doctorado con una tesis acerca de las ilustraciones del Quijote, tardó en reunir sus breves ensayos de anteguerra, pero al fin los editó en 1941 bajo el título Literatura española siglo XX (y resituaremos más adelante sus ensayos posteriores La poesía de Rubén Darío —1946-, Jorge Manrique, o tradición y originalidad —1947_, y El defensor —1948-); Dámaso Alonso publica La lengua poética de Góngora en 1927, pionera manufactura en la que al cabo se fabricarían sus ensayos literarios de posguerra; y Juan Chabás, miembro del Centro de Estudios Históricos y participante activo en el homenaje sevillano a Góngora de 1927, publica su Vuelo y estilo. Estudios de literatura contemporánea en 1934.

\section{En voz baja}

La Guerra Civil segó vidas, quebró edificios en construcción y truncó trayectorias; en suma: acabó con muchas cosas, entre ellas con la labor de la escuela española de Filología; pero ante todo, en lo que nos atañe, el resultado de la contienda determinaría durante años el ámbito y alcance del yo ensayista por un lado y la naturaleza y amplitud del público receptor por el otro. Entre ambos polos del acto de comunicación ensayístico, el desgarro de la confrontación no siempre dividió con precisión determinados entusiasmos, antaño comunes. Las escuelas estilísticas de Amado y Dámaso Alonso se erigen en ejemplo revelador de algunas continuidades. Amado Alonso, discípulo de Ramón Menéndez Pidal en el Centro de Estudios Históricos y especialista en fonética y geografía lingüística, residente en Argentina desde 1927 y director del Instituto de Filología de la capital bonaerense, edita tras la Guerra su Poesía y estilo de Pablo Neruda (1940), libro en el que formulaba la ciencia literaria estilística y que anunciaba ensayos ulteriores, como el capital Materia y forma en poesía (1955). Dámaso Alonso, por su parte, también discípulo de Ramón Menéndez Pidal, formula en España su peculiar estilística en libros como La poesía de San Juan de la Cruz (1942), Ensayos sobre poesía española (1944), 
y el capital Poesía española. Ensayo sobre métodos y límites estilísticos (Garcilaso, fray Luis, San Juan, Lope, Góngora y Quevedo) (1950). La voz, tono, entusiasmo y singular escritura ensayística de Dámaso Alonso (inolvidables los emotivos y recurrentes jay! de sus textos, en puridad ecfonemas retóricos) conformaron, para desgracia de muchas monografías fundadas en esta personal estilística alonsiana, una escuela a menudo extraviada entre la cursilería y el comentario intuitivo. No fue el caso, por descontado, de Carlos Bousoño y su temprano La poesía de Vicente Aleixandre (1950) ni el libro escrito junto a Dámaso Alonso Seis calas en la expresión literaria española (1951).

Pero es indudable que en España la Filología vivió por entonces su particular purgatorio filológico (Mainer 2003), espacio que propició un repliegue bien al academicismo rancio, bien al tratadismo doctrinario o bien a la erudición comarcana amparada en los Institutos de Estudios locales dispersos por la geografía nacional. Las limitaciones reales de la libertad de expresión del yo ensayista (recluido, retraído en la Universidad), la vigilada elección de temas no palpitantes (cuanto más arqueológicos, mejor) o la mengua del número y calidad del público lector curioso de la materia filológica, resultaron condiciones suficientes para que los ensayos fueran menos ensayos en tanto que pronunciados con esa cautelosa y apagada «voz baja» de la que hablaba Alonso Zamora Vicente en su «prologuito» de Presencia de los clásicos (1951); en este sentido, los ensayos, en cuanto tales, no es que disminuyeran tanto en número, sino sobre todo en grado. Pero los hubo, unos más resistentes y menos silenciosos que otros (Gracia 2004), y cuyos mérito y alcance rescató José-Carlos Mainer en su libro La Filología en el purgatorio. Entre ellos, los de Guillermo Díaz Plaja, quien se había estrenado tempranamente con Rubén Darío (1930) y su Introducción al estudio del Romanticismo español (1936), pero que destacó tras la Guerra Civil con La ventana de papel. Ensayos sobre el fenómeno literario (1939) y con su muy leído Modernismo frente a noventa y ocho (1951; relacionado, claro es, con La Generación del 98 —1945- de Pedro Laín Entralgo); los de Francisco Ynduráin, con su El Quijote y don Quijote (1950) o Mística y poesía en San Juan de la Cruz (1953), pero sobre todo con sus ensayos de 1969 Clásicos modernos y Relección de clásicos; los de José Manuel Blecua, el gran editor de clásicos como Quevedo y mentor de tantos filólogos, quien junto a Ricardo Gullón editó en 1949 La poesía de Jorge Guillén (dos ensayos); los del propio Gullón, autor de ensayos de categoría, como el Galdós, novelista moderno (1966), Direcciones del Modernismo (1966) y La 
invención del 98 y otros ensayos (1969); los de Alonso Zamora Vicente, maestro en la edición de misceláneas de ensayos breves, quien hubo de editar en Buenos Aires su recopilación de textos De Garcilaso a Valle-Inclán (1950) y en Madrid Presencia de los clásicos (1951), Voz en la letra (1958) o Lengua, literatura, intimidad (1966); los de Emilio Alarcos, quien publicaría en la madurez la mayor parte de sus ensayos filológicos literarios de fuste, como La poesía de Blas de Otero (1966), o Ángel González, poeta: variaciones críticas (1969); los de Fernando Lázaro Carreter, señaladamente los recogidos en Estilo barroco y personalidad creadora (1966); los de Rafael Lapesa, a quien siempre deberemos La trayectoria poética de Garcilaso (1948), La obra literaria del Marqués de Santillana (1957) y las compilaciones de ensayos De la Edad Media a nuestros días (1967) y De Ayala a Ayala (1977); los de Martín de Riquer, pues deliciosamente ensayísticos son muchos de sus escritos, por ejemplo su Aproximación al «Quijote» (1969); los de, en fin, José María Valverde, filósofo que nunca abandonó su inicial vocación filológica, no solo por su recopilación de ensayos de 1952 Estudios sobre la palabra poética, sino también por sus lecturas, tan ensayísticas, ofrecidas en Azorín (1971) y en Antonio Machado (1975), o por la rica prosa de sus textos para la Historia de la literatura universal, obra escrita junto a Martín de Riquer (1956).

Y si en la España de la alta y media posguerra la ausencia de libertad, del nutriente esencial para la floración robusta del moderno y liberal ensayo, explica la voz baja de muchos ensayos que por tal razón lo fueron menos, en la España trasterrada fueron otras las condiciones que menoscabaron el número o grado excelente de los ensayos. Entre ellas, la mayor, la que atañe a la falta de público cómplice (el ¿para quién escribimos nosotros? de Francisco Ayala) y otra, no menos importante quizá, la particular vivencia de un pathos, entre desgarrado y melancólico, común en los exiliados. En España el campo literario se achicó hasta convertirse en celda purgatoria; en el destierro aquella habitación frágil, desprotegida, estuvo expuesta siempre a las inclemencias, a la intemperie. No extraña que muchos de los ensayos filológicos de autores exiliados terminasen publicándose en España; fue el caso de Joaquín Casalduero, discípulo aventajado de Ramón Menéndez Pidal en el Centro de Estudios Históricos, a quien Ínsula editó su Sentido y forma del "Quijote» en 1949 y, dos años más tarde, Aguilar su Sentido y forma del teatro de Cervantes; de Jorge Guillén, autor de una tesis sobre Góngora antes de la Guerra, cuyo libro Lenguaje y Poesía fue acogido en 1962 por la editorial de Revista de Occidente un año 
después de su original en inglés; de José Fernández Montesinos, discípulo de Américo Castro y uno de los más excelentes editores de clásicos literarios — Lope, los hermanos Valdés...— antes de la contienda del 36, quien envía desde Berkeley a Zaragoza para su publicación el original del Pedro Antonio de Alarcón (1955), y en 1957 a Madrid el de su clarividente Valera o la ficción libre: ensayo de interpretación de una anomalía literaria, que tanto debía a los magistrales ensayos de Manuel Azaña sobre Valera; o de Juan Marichal, alumno de Américo Castro en Princeton, cuya seminal La voluntad de estilo. Teoría e historia del ensayismo hispánico (1957) fue editada por la barcelonesa Seix Barral. Otros ensayistas en el exilio, sin embargo, tuvieron la suerte (o el infortunio, según se mire) de publicar en editoriales mejicanas, argentinas o estadounidenses, como en el caso de Pedro Salinas con los ya citados La poesía de Rubén Darío. Ensayo sobre el tema y los temas del poeta (1946), Jorge Manrique, o tradición y originalidad (1947), y El defensor (1948). El de Vicente Lloréns es extremadamente revelador, pues su ejemplar Liberales y románticos. Una emigración española en Inglaterra (1823-1834) (1954) refleja en último término, y en forma de ensayo, la propia existencia del filólogo condenado a un exilio cuya genealogía anda inquiriendo, de ahí que la abundante erudición del estudio sea eclipsada por la emoción del autor que la avala y que, en muchos pasajes, consigue transmutar la monografía en ensayo.

\section{Una intensidad y un tono recuperados}

Por fortuna, las condiciones que sometían a la cultura española cambiaron notablemente cuando corrían bien avanzados los años de la década de los sesenta. En lo que más importa a la trama de estas páginas, las universidades comenzaron a llenarse de más y más alumnos, se duplicaban cátedras, se instalaron nuevas universidades y comenzaron a impartir clases una legión de jóvenes profesores (no numerarios) en su mayoría concernidos en la tarea de recuperación de una normalidad moderna que pasaba, entre otras muchas tareas, por reconquistar territorios allende ese espacio achicado, recoleto, de los años de purgatorio. En el ámbito filológico, se multiplicaron las voces autorizadas susceptibles de ensayar, se agrandó el público interesado en oírlas y en compartir un mismo aliento, bien por el aumento del número de universitarios, bien por la creación de colecciones de clásicos literarios a precios asequibles, bien por la constante y, a menudo apresurada, traducción de textos críticos y teóricos fundamentales de autores foráneos. 
Para completar la refundación de un ancho (y oreado) campo propicio al ensayo restaba un ingrediente fundamental: el atrevimiento (insolencia, diríamos, en aquellos años crepusculares de los sesenta y principios de los setenta), la osadía de ensayar, de terminar con un largo periodo de susurros y textos en voz baja.

A la tarea de recobrar la clave necesaria para imponer la altura de composición de los buenos ensayos filológicos coadyuvaron al menos dos certezas: la una, que por entonces la autoridad innegable de maestros filólogos como los citados José Manuel Blecua, Emilio Alarcos y Rafael Lapesa —pero también los Martín de Riquer o Antonio Vilanova, entre otros-, pudo transmitirse con mayor naturalidad (o mejor, normalidad) en las aulas universitarias a jóvenes que, en muchos casos, lucrarían al poco de egresar contratos como profesores en aquellas mismas salas: se retomaba, por tanto, una tradición; y la otra, que se leyeron y difundieron ensayos de profesores que señalaban nuevos objetos de materia ensayable palpitante en tanto que colonizaban periodos de la historia literaria comprometidos: se pretendía añadir con naturalidad, por tal razón, determinados autores, libros y épocas al canon aceptado como clásico. Uno de aquellos profesores fue Gonzalo Sobejano, docente en universidades yanquis, quien entre 1967 y 1970 publica nada más y nada menos que libros señeros como Forma literaria y sensibilidad social: Mateo Alemán, Galdós, Clarín, el 98 y Valle-Inclán (1967), Nietzsche en España (1967), Novela española de nuestro tiempo: en busca del pueblo perdido (1970), o bien ensayos breves que valen por uno maior como el barojiano «Solaces del yo distinto (Estimación de Juventud, egolatría)», aparecido en el número 308-309 de la revista Ínsula (1972); otro caso fue el de Carlos Blanco Aguinaga, exiliado en Méjico y en aquellos años también profesor en universidades estadounidenses como Gonzalo Sobejano, cuyo original de Juventud del 98 hubo de acoger y editar Siglo XXI en el año de 1970, mientras que Laia reeditaría años más tarde (1975) su ensayo capital, El Unamuno contemplativo (1959); o el de Enrique Moreno Báez, en su día heredero del lectorado de Dámaso Alonso en la Universidad de Oxford, con su ensayo Reflexiones sobre el Quijote, de 1968; el de Rafael Pérez de la Dehesa, docente en Berkeley, y autor de ensayos tan leídos por los jóvenes filólogos del momento como los trascendentales Política y sociedad en el primer Unamuno (1966) o El grupo «Germinal», una clave del 98 (1971); y el de Ignacio Soldevila, catedrático en la Universidad Laval de Quebec, quien en 1973 publica La obra narrativa de Max Aub en Gredos. Aquellos años fueron también, no lo olvidemos, los de la recepción amplia y 
comienzo del reconocimiento de la obra literaria —incluida la ensayística — de Francisco Ayala, cuyo oficio crítico tanto hubo de cruzarse con el de Ignacio Soldevila.

Con el restablecimiento paulatino de una tradición en las aulas y en los circuitos de difusión de la alta cultura, la recuperación de voces de la lejanía trasterrada y la convicción de estar viviendo una especie de pathos colectivo en el que se percibía con entusiasta urgencia la necesidad de ensanchamiento (político, intelectual) de los todavía angostos y asfixiantes cauces culturales, solo restaba, decíamos más arriba, la osadía de ensayar. Y atrevida, muy atrevida, fue la edición del ensayo filológico (y antología) Falange y literatura por parte de su autor, el por entonces joven profesor universitario José-Carlos Mainer. Ya el propio título del original, firmado en diciembre de 1972 (¡diciembre de 1972, casi tres años antes de la muerte de Francisco Franco!), manifestaba no tanto una cautela política como intelectual: no se llamó La literatura de Falange, sino que el uso de un calculado hendíadis fundía en un único concepto los dos términos coordinados. Esta simple figura retórica establecía una meridiana clave de ensayo por la cual se anunciaba que aquello que el lector tenía en sus manos no era un estudio filológico más, sino un ensayo, una forma consciente de transmisión de meditaciones autorizadas que desde el uso calculado de la elocutio lo alejaban de un tratadismo ralo. Allí no finalizaba el atrevimiento, por descontado, toda vez que José-Carlos Mainer señalaba un territorio comprometido al reflexionar acerca de autores y obras de filiación falangista nada menos que en 1972: hasta cierto punto se finiquitaba - filológicamente hablando - toda una anomalía y parte de un periodo, el del primer franquismo, que Mainer razonaba (desde modernos presupuestos sociológicos e intelectuales) y por el que se explicaba a sí mismo desde una voz de timbre muy reconocible; en otras palabras, Mainer cumplía una de las condiciones esenciales del ensayo al comunicar «un ethos irrenunciable que señala la necesidad de sentirse concernido en aquello que se pretende explicar» (Ara Torralba :7). La autoridad de José-Carlos Mainer en dominar (y señalar, no olvidemos) periodos de nuestra historia literaria poco reconocidos hasta el punto de lograr elevarlos a categoría tan prestigiosa como los que cobijaba el marbete de Edad de Oro, quedó demostrada en uno de los más aclamados ensayos filológicos de nuestra tradición: La Edad de Plata (1902-1931). Ensayo de interpretación de un proceso cultural, en parte anticipado por otro puro e influyente ensayo de 1972, Literatura y pequeña burguesía en España. Notas (1890-1950) y por otra no menos libre y estimulante lectura como la expuesta en Análisis de 
una insatisfacción: las novelas de W. Fernández-Flórez (1975). Ya los colores de la cubierta de la primera edición de La Edad de Plata (Barcelona, LosLibrosDeLa Frontera, 1975), rojo, amarillo y morado, guiñaban, avisaban de manera cómplice al lector del ensayo. Y la propia palabra ensayo podía leerse tanto en el subtítulo (donde no aparece la palabra literatura sino proceso cultural) como en el prólogo firmado en Barcelona y mayo-septiembre de 1974; allí decía el propio Mainer de su libro, La Edad de Plata,

\footnotetext{
que no ha perdido, evidentemente, la frágil condición de tal que tenía desde su origen. Quiero decir con ello que, surgido de cara a las necesidades de públicos bastante variados, no se trata de un trabajo erudito sino, como indica su subtítulo, de un intento de interpretación global de una etapa de la cultura española, pensada para divulgar unas ideas muy básicas entre una audiencia de estudiantes de segundo y tercer curso o de simples lectores rasos de las obras que aquí se comentan. He de confesar que mi admiración por la habilidad expositiva de la alta divulgación anglosajona fue otro ingrediente en la elaboración de este libro (Mainer 1975:15)
}

¡Cuántas características del ensayo pueden leerse en tan pocas líneas!: la captatio benevolentiae del prologuista, la mostración de un yo confidente, la asunción de un género todavía por recuperar — frágil— la modelación implícita del público lector, el afán por sintetizar, la búsqueda de un marco explicativo superior donde realmente se termina de entender la labor literaria, el reconocimiento de la eficacia de métodos expositivos hábiles que seduzcan a un público amplio sin ceder un ápice de altura especulativa... Aquellos propósitos de 1975 perseveraron en la amplia trayectoria ensayística de Mainer. Al cabo en sus ensayos siempre persiste la reflexión del lugar, el yo, desde donde se escribe el discurso («la necesidad personal de explicarse algo, o quizá de explicarse uno mismo» (Mainer 2003:9)), el para quién se escribe, el alcance histórico de lo literario, sus límites y contornos (léase Historia, literatura, sociedad, de 1988), el interés último por la reflexión y crítica literarias, siempre sustanciado en un juego meditativo en torno a tramas, nombres, libros (Mainer 2005)... en definitiva, la exposición ética, y aun patética, inherente a todo ensayo filológico de calidad: «Y reconozco que soy cada vez más partidario de la lectura moral (e histórica, claro: no hay moral sin historia y viceversa). A eso le llamo (...) «entender la historia de la literatura»» (Mainer 2005:11). 
Y todo ello en un estilo propio (como respuesta a una nueva pregunta: la de cómo relatar la literatura), de elocución meditada, que en el caso de José-Carlos Mainer traslada los interrogantes y principios arriba indicados a una escritura seductora, de musicalidad argumentativa, donde, no es casualidad, abundan la variatio y las diferentes figuras retóricas de la descripción: enumeraciones, evidencias, etopeyas, retratos, topografías... cuya naturaleza y objetivos clasificatorios a menudo se proyectaban, bien a la ilustración de una cubierta (piénsese en el Cartel de Giménez Caballero, ese mapa Universo de la literatura en España, para la primera edición de La Edad de Plata), bien a títulos de libros o artículos: geografías, inventarios, topografías, galerías de retratos, mapas, histologías, radiografías, cartografías, lugares...

También Francisco Rico comenzó su labor filológica en los años de agonía del franquismo. No sorprende que su ejecutoria profesional desde fines de los sesenta hasta el inicio de los ochenta se asemeje tanto a la de muchos componentes de la Escuela de Filología Española de anteguerra. En verdad se estaba recuperando una tradición, pues con aquellos discípulos de los Pidal o Castro, Francisco Rico habría de compartir, cincuenta años mediante, afanes y propósitos similares: edición crítica de clásicos acompañada de monografías fundamentales (La novela picaresca y el punto de vista — 1970 - cuyo arranque prologal ya se leía como puro ensayo, Alfonso el Sabio y la "General Estoria». Tres lecciones - 1972—...), promoción y dirección de colecciones de autores esenciales de nuestra historia literaria para diferentes rangos de público (universitario, de enseñanza secundaria, culto...), y redacción de libros que pretendían anclar la tradición literaria española en su debido contexto cultural europeo, románico. Porque a ese designio respondieron títulos inexcusables como El pequeño mundo del hombre. Varia fortuna de una idea en la cultura española (1970), estudio del fecundo topos donde resonaban las voces de Ernst Robert Curtius, por descontado, pero también las de maestros del interior como Martín de Riquer y José Manuel Blecua, y del exterior como María Rosa Lida o Eugenio Asensio. En cierto modo aquel designio era común al defendido por José-Carlos Mainer cuando hablaba de la necesidad de reinterpretación de la historia literaria dentro de un contexto cultural superior, solo que Rico incidió no tanto en tramas, libros y nombres, como en tradiciones, géneros y valores; así lo expuso en el prólogo a Textos y contextos. Estudios sobre la poesía española del siglo XV: 


\begin{abstract}
El crítico se deslumbra a veces con la ilusión de encerrarse en el poema como en un universo que se basta a sí mismo y que proporciona desde dentro la totalidad de las claves para descifrarlo. El historiador sabe que el texto no es comprensible sin contextos, ni aun existe sin ellos, porque tampoco existe sino en una lengua y en las coordenadas de una sociedad, sobre el fondo de unas tradiciones, con unos ideales artísticos, frente a un horizonte de géneros, en un sistema de valores... A un texto de otros tiempos, en particular, o lo restituimos a los contextos que le son propios, o bien, a conciencia o a ciegas, le imponemos los nuestros. Nihil est tertium (Rico 1990: IX)
\end{abstract}

Porque Francisco Rico, como José-Carlos Mainer, también ha gustado de ensayar, de probar nuevas formas genéricas para transmitir conocimientos filológicos. En 1982, Rico edita Primera cuarentena y Tratado General de Literatura, en cuyo prólogo el autor, desde un sólido yo que, cumplidos los cuarenta años, expone y conversa con el lector, confiesa que «A cierta altura de mi historia, y de la bibliografía, estas páginas dicen también la nostalgia de un modo de hacer más suelto y menos aburrido, más a la medida de un hombre y menos a la hechura de las escuelas» (Rico: 1982:9).

Primera cuarentena es, en efecto, un novedoso molde ensayístico porque prueba fórmulas de la literatura del yo como el dietario personal —-también José-Carlos Mainer ensayaría algo similar en el libro de 1994 De postguerra (1951-1990) — y porque disemina, de manera lúdica, en constante juego con el lector, temas y problemas filológicos en un despliegue discursivo que aprovecha las virtudes y defectos de los mejores cuadernos de notas y de diarios. Dos décadas después, cumplida la sesentena, un libro recopilatorio de ensayos y textos breves de diversa índole (Los discursos del gusto. Notas sobre clásicos y contemporáneos -2003-) fue asimismo introducido por un prólogo en el que se defendía, por un lado, un carácter personal y, por el otro, se postulaba un modo de entender la historia de la literatura homólogo al de José-Carlos Mainer. Para Rico, Los discursos del gusto es un conjunto:

a medio camino entre el diario de lecturas, o el Büchertagebuch, aleatorio y caprichoso, y el diario de operaciones, testimonio de la pequeña campaña — personal, marginal y, naturalmente, fallida, como todo aquí- que en los dos decenios de marras he desplegado a favor de un cierto modo de entender y gustar la literatura (Rico 2003: 9) 
Es evidente que, como Mainer, Rico también ha meditado acerca de quién, para quién y de qué modo se escribe un texto filológico: de la manera de entender la literatura y de cómo la autoridad y el sustrato erudito de cualquier estudio pueden transformarse en ensayo a través de esa especie de libertad rigurosa (Fernando Lázaro dixit sobre el quehacer de Rico) que en el caso de Francisco Rico se traduce en una escritura de elocución clásica, perspicaz e ingeniosa, no exenta de humor, ironía y hasta mordacidad: de una constante conversación con el lector al que siempre invita a leer el texto como algo vivo y divertido, como festín lúdico, nunca como fetiche reverencial. Ni siquiera la edición de los clásicos ha de ser «sólo (...) fabricación de meros productos para eruditos» (Rico 2004:10-11), entre otras cosas porque Francisco Rico es plenamente consciente de los diferentes géneros por los que puede discurrir la Filología, desde los de la más encorsetada tesis hasta aquellos por los que la Filología, en efecto, se hace ensayo, como ocurre con su ejemplar, en este sentido, Figuras con paisaje (1994). Así lo expuso en esta cita del prólogo a Estudios de literatura y otras cosas, texto que, por clarividente, podría haber servido como exergo introductorio de estas páginas:

\footnotetext{
Yo he cometido tesis (que duermen el sueño a pierna suelta de los pecadores), ediciones, libros (y hasta algún book), artículos..., y confieso no haber tenido nunca ideas firmes (tampoco) sobre la jerarquía y dignidad de cada especie. Cuando una cuestión me ha atraído, le he dado, si podía, el tratamiento, las dimensiones y la forma que me parecían imprescindibles para hacerle justicia. En cambio, sí he tenido, y muy firme, la conciencia de que en la filología y en la historia existen géneros (deseablemente literarios) menos variados pero entre sí no menos dispares que en la creación: géneros cuyas exigencias propias Ilegan a determinar no ya la presentación, sino (como tenemos entendido los lectores de física recreativa) la entidad misma del tema abordado (...) Un libro, un libro de veras, difícilmente puede no ser un ensayo: un asunto con la envergadura suficiente para pedir un libro contiene por fuerza tantas facetas, y tan complejas, que sólo cabe mostrarlas a través de una meditada selección de hechos sugestivos (Rico 2002:9-10)
}

También Domingo Ynduráin probó, aquí y allá, una escritura allende la académica. Hijo de Francisco Ynduráin, fue Rafael Lapesa quien le redactó el delantal para su juvenil estudio Análisis formal de la poesía de Espronceda (1971). Era tal la seriedad del formalismo estilístico de Ynduráin empleado en el análisis, que el propio autor vio casi necesario ensayar, a modo barojiano, un delicioso y desenfadado «Desahogo teórico y casi doctrinal» a modo de prólogo; 
fue este prólogo al lector texto exculpatorio de la gravedad de lo que se le venía encima a aquel si seguía leyendo: «El lector no está obligado ni tiene necesidad de leerlo, pero se le ofrece un poco en compensación de lo que, si persevera, le aguarda» (Ynduráin :17). Este exabrupto lúdico (exabrupto porque el prólogo seguía nada menos que a la presentación severa de don Rafael Lapesa), tan de Rico e Ynduráin (quien también huía del tratamiento reverencial a los clásicos), debe leerse como demostración del manejo atrevido de una voz que sabe distinguir qué cosa sea un ensayo filológico y qué cosa no. Voz, sujeto que, en el caso de Domingo Ynduráin, acertó a escribir Ideas recurrentes en Antonio Machado (1975), con prólogo de Aurora de Albornoz, o los excelentes tomos recopilatorios de ensayos, Humanismo y Renacimiento en España (1994) y Del clasicismo al 98 (2000), volumen este donde perseveró en sus viejas afinidades con ese Pío Baroja, de humor escéptico y juguetón, que siempre se sintió a gusto en el tono confidencial y en la divagación lúdica desplegada en prólogos y epílogos.

A esta cita de exhibición de voluntad de estilo que moldeaba el objeto literario con un mimo más allá del académico, no faltaron otros, a la sazón, jóvenes filólogos que con el tiempo también se convirtieron en maestros y modelos; a ellos deberían sumarse dos que ya no lo eran tanto (jóvenes, queremos decir): el siempre recordado Juan Manuel Rozas, autor de los fundamentales La generación del 27 desde dentro (1974) o Intrahistoria y literatura. Tres lecciones a modo de ensayo (1980) y un ensayista de larga distancia como Carlos Pujol, cuyos Juan Perucho (1986) y 1900. Fin de siglo (1987) se leen con el mismo deleite que sus meditaciones Balzac o la comedia humana (1974) o Leer a Saint-Simon (1979). Ahora bien, retornando a los por entonces jóvenes, y sin ánimo de exhaustividad, no deberían faltar en este repertorio el magisterio de Aurora Egido, cuyo timbre ensayístico resuena en Cervantes y las puertas del sueño. Estudios sobre "La Galatea», "El Persiles» y «El Quijote» (1994), La voz de las letras en el siglo de Oro (2003), o en los despuntes y pespuntes de El Barroco de los modernos (2003), el decisivo y temprano ensayo de Joan Oleza La novela del siglo XIX. Del parto a la crisis de una ideología (1976), los libros de otro discípulo de José Manuel Blecua, Joaquim Marco, desde su inicial Ejercicios literarios (1969) hasta La llegada de los bárbaros. La recepción de la literatura hispanoamericana en España, 1960-1981 (2004: coeditado con Jordi Gracia), pasando por volúmenes esenciales como El modernisme literari $i$ altres assaigs (1983), los de Manuel Aznar Soler, Valle-Inclán, Rivas Cherif y la renovación teatral española 1907-1936 (1992) o Los 
laberintos del exilio (2002), y, por descontado, el magistral En el texto de Garcilaso (1970) de Alberto Blecua. Mención destacada, en punto a resaltar la búsqueda de públicos amplios y de un estilo peculiar — desenfadado— de ensayar, tiene la labor de Agustín Sánchez Vidal, quien en 1988 obtuvo el premio de ensayo «Espejo de España» de Planeta con el libro Buñuel, Lorca, Dalí: el enigma sin fin (1988).

Asimismo, libros de veras, ensayos, fueron aquellos editados durante las calendas de la década de los setenta por escritores filólogos como Rafael Sánchez Ferlosio (Las semanas del jardín -1974- es un libro, de título tan cervantino, todavía por reconocer en su verdadero y original alcance) o José Ángel Valente (Las palabras de la tribu —1971—; «Ensayo sobre Miguel de Molinos», texto que precede a la edición de la Guía Espiritual —1974-), escritos desde voces atrevidas y reivindicadoras de nuevos espacios de libertad interpretativa (aquellos por los que había transitado Jaime Gil de Biedma, quien en 1980 recoge sus ensayos literarios en El pie de la letra). Participaban también de un mismo pathos, por entonces definido con el nebuloso adjetivo de heterodoxo, los ensayos literarios contemporáneos de Pere Gimferrer ( $L a$ poesía de J. V. Foix —1974—; Radicalidades -1978—; Lecturas de Octavio Paz —1980—) o Juan Goytisolo (El furgón de cola —1976-). El atrevimiento heterodoxo por reivindicar un lugar de estudio filológico para lo que hasta entonces se entendía por subliterario (voluntad de prestigiar lo marginal común con la del Manuel Vázquez Montalbán de la Crónica sentimental de España -1971—) vino de la mano de otro joven profesor universitario, Andrés Amorós, autor de la Sociología de una novela rosa (1968) y de la recopilación de ensayos que tituló, elocuentemente, Subliteraturas, en 1974 (de 1976 data el libro de Leonardo Romero Tobar, La novela popular española del siglo XIX, de 1977 Literatura popular en España en los siglos XVIII y XIX, de Joaquim Marco, y de 1982 Teoría y mercado de la novela en España, de Luis Fernández Cifuentes). Ciertamente, fueron aquellos años de recuperación paulatina de las condiciones para ensayar muy fecundos en textos que continuaban con la tradición de ir señalando, acotando nuevos territorios para la historia literaria; y lo hacían desde voces distintas (con voluntad firme de ser reconocidos sus timbres) como lo fue la de Guillermo Carnero al mostrar La cara oscura del siglo de las luces (1983), en un ensayo acerca de un periodo que todavía estaba a la espera de repertorios y bases bibliográficas fiables... y escritos los textos que lo componen con el mismo propósito de exclusión de la erudición roma del que haría gala en el prólogo de Las armas 
abisinias. Ensayos sobre literatura y arte del siglo XX (1989); o la de Santos Sanz Villanueva, cuya Narrativa en el exilio (capítulo del volumen cuarto de la obra coordinada por José Luis Abellán, EI exilio español de 1939 -1977—) es seminal reflexión acerca de la naturaleza, límites y alcance de la literatura trasterrada. Complementaria, en cierto modo, fue la tarea de aquellos ensayos filológicos que, en la senda de la manera de entender la literatura de Rico y Mainer, reclamaron la necesidad de comprenderla dentro de círculos interpretativos amplios, como eran los defendidos desde el comparatismo literario. Así, la de Claudio Guillén, discípulo intelectual de Joaquín Casalduero y José Ferrater Mora (autor de una impagable compilación de ensayos literarios, El mundo del escritor —1983-), quien, instalado en España desde 1982, habría de publicar su esencial obra Entre lo uno y lo diverso. Introducción a la literatura comparada (1985), a la que seguirían Múltiples moradas: ensayo de literatura comparada (1998) y Entre el saber y conocer: moradas del estudio literario (2001); y así, la de Darío Villanueva, autor del sugerente El polen de ideas. Teoría, Crítica, Historia y Literatura Comparada (1991). Y qué decir de la ampliación de campo no solo geográfica, sino hacia territorios artísticos afines, como los cinematográficos: allí sobresalió la labor de Jorge Urrutia, con su seminal La literatura española en el cine (Bases para un estudio) (1972) — continuada con Imago litterae. Cine. Literatura (1983)—, pero a quien debemos también otros buenos ensayos, como La pasión del desánimo: la renovación narrativa de 1902 (2002).

\section{Años de cosecha}

Los años ochenta y noventa del siglo pasado fueron los del asentamiento y progresión (numérica y cualitativa) de los departamentos universitarios de Filología Española al socaire de la Ley de Reforma Universitaria (1983). En ellos se cosecharon los frutos y avances del magisterio de los ya por entonces maduros profesores de los sesenta y setenta, de tal modo que el progreso en monografías, artículos, manuales... por parte de decenas de nuevos profesores se tradujo en una sistemática colonización, cuando menos positiva, de prácticamente todos los territorios de la historia de la literatura española (y a su imagen y semejanza, de las diferentes historias autonómicas, no lo olvidemos) tal como la conocemos en los días que corren. Ahora bien, a despecho de las consecuencias derivadas de esta razón positiva, el campo del ensayo filológico no empequeñeció rodeado por los cientos, y muy buenos en ocasiones, tratados 
especializados de los sucesivos cadetes de filólogos: quizá Guillermo Carnero exageraba cuando hubo de explicar (y justificarse) la selección de sus ensayos para Las armas abisinias (1989) alegando este criterio de exclusión: «la excesiva especialización, la erudición y los intereses científicos privativos del guetto universitario» (Carnero :10). Ni la especialización compulsiva (resultado de la convicción, muy opinable, de que determinados temas y periodos de estudio literario van siendo esquilmados), ni la pizca de pereza por buscar un público amplio, ni el escaso y tímido atrevimiento a salir del recinto scholar (dominado por requisitos y rutinas) de algunos, impidieron la escritura de muchos ensayos filológicos tout court, tanto la que siguieron cultivando los ya maduros y antiguos penenes de los setenta, ahora en justicia catedráticos, como la de nuevas voces que ampliaron campo y modelos de ensayar teniendo en cuenta la de sus inmediatos antecesores. Y al hablar de estas voces nuevas que al cabo resonarían, brillantes, en nuevos modelos de ensayo, es justo señalar en primer lugar la del poeta y profesor Andrés Sánchez Robayna (delicioso su maduro Deseo, imagen, lugar de la palabra, de 2008), pero también la de Andrés Soria Olmedo (desde su Vanguardismo y crítica literaria en España, de 1988; aunque Fábula de fuentes, de 2004, es un ejemplo de calidad de prosa y voluntad de estilo inconfundibles), o la del Luis García Montero más reciente, la de Los dueños del vacío (2006), Inquietudes bárbaras (2008) o del todavía fresco Un lector Ilamado Federico García Lorca (2016). Un repertorio más exhaustivo de ensayos de valor indudable debería acoger, sin duda, los de Javier Blasco (de Poética de Juan Ramón Jiménez -1982 - a Cervantes, raro inventor —1998-, por lo menos), los de José Luis Calvo (La cara oculta del 98 - 1998 - es un buen ejemplo, pero más regocijado y suelto La palabra inflamada, del 2000), de Bienvenido Morros (Las polémicas literarias en la España del siglo XVI, editado en 1998), de Jesús Gómez (El diálogo en el Renacimiento español, de 1988), de José María Micó (entre su pionero La fragua de las «Soledades»: ensayos sobre Góngora, de 1990, y sus Clásicos vividos, de 2013), de Javier Huerta Calvo (debe citarse El nuevo mundo de la risa: estudios sobre el teatro breve y la comicidad en los siglos de Oro, de 1996), de Guillermo Serés (con su, ya «clásico», La transformación de los amantes. Imágenes del amor de la Antigüedad al siglo de Oro, de 1996), de Gonzalo Santonja (La República de los libros. El nuevo libro popular de la II República -1989-), de Jesús Rubio (poeta en ratos de ocio, y autor del seminal Ideología y teatro en España: 1890-1900, editado en 1982), de Ángel Luis Prieto de Paula (ágil y esclarecedora su Musa del 68: claves de una 
generación poética, de 1996), de Fernando Baños (La hagiografía como género literario en la Edad Media, de 1990), de Pedro Ruiz Pérez (El espacio de la escitura. En torno a una poética del espacio del texto barroco, de 1996, o La distinción cervantina. Poética e historia, de 2006), de Pura Fernández (Eduardo López Bago y el naturalismo radical, de 1995) o Javier Serrano Alonso (excelente discípulo de Domingo Ynduráin, en Los cuentos de Valle-Inclán, de 1996).

Aunque no ayudaba, es verdad, cierta autocomplacencia de la sociedad que vivía con naturalidad un proceso de normalización de la vida colectiva, hubo por aquellas décadas de los ochenta y noventa, eso sí, lugares palpitantes que provocaron entusiasmos y atrevimientos para el ensayo de raíz filológica en búsqueda de un público todavía más amplio. De uno de aquellos, el de la llamada cuestión vasca, osó ensayar Jon Juaristi; porque desde la literatura —entre otros territorios para entender aquella cuestión — más una fuerte carga ética y patética hubo de publicar El linaje de Aitor. La invención de la tradición vasca (1987), al que siguieron El chimbo expiatorio (La invención de la tradición bilbaína. 1876-1939) (1994) y El bucle melancólico. Historias de nacionalistas vascos (1997). Por su parte, Andrés Trapiello transitó por lugares propensos al comentario y polémica con estudiosos y eruditos, como los de Cervantes (Las vidas de Miguel de Cervantes. Una biografía distinta - 1993-), los de la Guerra Civil (Las armas y las letras. Literatura y Guerra Civil (1936-1939) - 1994-), o los de un 98 a punto de conmemorarse (Los nietos del Cid. La nueva Edad de Oro (1898-1914) -1997-; en parte anticipado en la galería personal de los Clásicos de traje gris —1990—).

\section{Un lugar para el noble arte del ensayo (filológico)}

A los muchos escenarios de oportunidades (según hemos dicho, esencialmente conmemorativos: tal centenario, tal sesquicentenario, pero también tal homenaje), se sumaron otros de invención personal como ocasiones para pensar por ensayos síntesis sugerentes de literatura española. Que el propio género del ensayo literario (no solo el filológico) comenzase a ser objeto de reflexión, síntesis y antología desde la disciplina filológica a mediados de la década de los noventa del pasado siglo propiciaría un mayor interés si cabe por la escritura del ensayo filológico. A la tarea de reconocer un lugar literario digno para el ensayo español (similar al de los géneros primarios) ayudó la publicación de los tomos dedicados al Ensayo español por parte de la editorial Crítica: el primero, de 1996, con jugoso prólogo de José-Carlos Mainer. Y precisamente 
el encargado de la que fue entrega $\vee$ de la colección (Los contemporáneos), Jordi Gracia, sería quien, con el paso de pocos años, más frecuentó la escritura de ensayos filológicos. Jordi Gracia había editado también en los noventa la sustancia de la que fue su tesis doctoral Estado y cultura. El despertar de una conciencia crítica bajo el franquismo (1996), pero con el nuevo milenio fueron apareciendo sus ensayos filológicos fundamentales: Hijos de la razón. Contraluces de la libertad en las letras españolas de la democracia (2001), uno de las primeras aproximaciones para el entendimiento de la literatura española desde 1975 hasta los días que corrían, la síntesis La España de Franco. Cultura y vida cotidiana (2001; junto al historiador Miguel Ángel Ruiz Carnicer), el premio Anagrama de Ensayo 2004 La resistencia silenciosa. Fascismo y cultura en España (2004), La vida rescatada de Dionisio Ridruejo (2008), A la intemperie. Exilio y cultura en España (2010), Burgueses imperfectos. Heterodoxia y disidencia literaria en Cataluña. De Josep Pla a Pere Gimferrer (2015, original en catalán de 2012), o su reciente intrusión en territorio cervantista Miguel de Cervantes. La conquista de la ironía (2016). Los ensayos filológicos de Gracia cumplen con creces los requisitos del género: desde la conciencia del yo y la responsabilidad ética, personal, la petición de benevolencia a un lector del que se espera sea partícipe de un pathos y entusiasmo común, la invención de lugares propicios para la conversación, el debate o la polémica, o la disposición hábil de argumentos y evidencias con un estilo muy estimulante. En los ensayos de Jordi Gracia hay siempre entusiasmo, vehemencia, nada de cursilería, huida de clichés, afán polémico... en una redacción plena de sentencias incisivas, de giros y perífrasis seductoras; pero en todo caso con una voluntad de entender la literatura de manera cultural (en la senda de su maestro José-Carlos Mainer), atenta a darle la vuelta a los lugares comunes y a determinadas opiniones aceptadas como verdades. Este fragmento del prólogo a La resistencia silenciosa es muy revelador de algunas de las características citadas:

Lo raro, sin embargo, entre la gente de mi edad, en torno a la cuarentena, es que la propensión mítica o legendaria la tenemos poco desarrollada. Quizá porque el sueño, o el señuelo, de la revolución nos llegó ya muy desactivado o cuando prácticamente todo había acabado. Ni siquiera nos adorna una derrota de bulto o la decencia de haber creído alguna vez en algo grande y verdadero. En una democracia sin barullo utópico, hemos cumplido la ruta de apacibles burgueses reformistas, votantes de izquierda con la conciencia tranquila, solidarios de cuenta corriente y manifestación invariablemente lúdica. No tenemos causas perdidas ni paraísos robados. Somos los 
primeros demócratas de toda la vida en España y no sé si eso imprime carácter o lo quita, pero en todo caso a mí me hace vagamente incrédulo ante las fiebres revolucionarias que nublaron la vista, hace ya más de muchos años, a escritores que son hoy ejemplares (Gracia 2004:16-17)

Pero también Domingo Ródenas de Moya, coautor, junto a Jordi Gracia, del tomo El ensayo español. Siglo XX (2009), tentó el género, ya desde 1998, cuando publicó Los espejos del novelista. Modernismo y autorreferencia en la novela vanguardista española, ensayo cuyo valor principal reside en el deslinde clarificador de las etiquetas moderno, modernista, modern, modernism; una labor que depuró todavía más si cabe en Travesías vanguardistas. Ensayo sobre la prosa del Arte Nuevo (2009), en cuyo prólogo el autor confiesa, zumbón, escribir «persuadido de que la monogamia metodológica es perjudicial para la salud (al menos para la salud intelectual)» (Ródenas: 15). Tal vez sea Javier Cercas uno de los escritores (y profesor universitario, no lo olvidemos) que mejor practica la poligamia metodológica y genérica en su peculiar scriptorium, y en punto a ensayos destacan tanto su inicial La obra literaria de Gonzalo Suárez (1993) como el recentísimo El punto ciego (2016), una verdadera anatomía de la novela, como lo había sido, pero estrictamente de la española contemporánea, el ensayo de Fernando Valls La realidad inventada. Un análisis crítico de la novela española actual (2003). Por su parte, para entender el proceso literario trazado por la poesía española de sesenta años acá han de leerse los ensayos de Juan José Lanz, al menos desde su Introducción al estudio de la generación poética del 68 (2001); y si hablamos de profesores ensayistas de los últimos años que han destacado por una escritura brillante, no deberían faltar en este apresurado catálogo los nombres y libros de Gonzalo Pontón Gijón (uno de los colaboradores de la Historia de la Literatura dirigida por José-Carlos Mainer), quien muestra una sorprendente soltura y maestría de estilo en Correspondencias. Los orígenes del arte epistolar en España (2002), y de José Jurado Morales en Las razones éticas del realismo. La «Revista Española» (1953-1954) en la literatura del medio siglo (2012). Por su parte, de las biografías modernist ha escrito con libertad rigurosa, y muy bien, José Enrique Serrano (Vidas oblicuas, de 2002), pero es más apreciable tal vez la que hubo de emplear para escribir el jugoso y lúdico Ramón y el arte de matar (1992), o la que desplegó José Luis Bernal en «Manual de espumas». La plenitud creacionista de Gerardo Diego (2008). Atrevidos (y por tanto más ensayos) suelen ser los textos de Javier Aparicio Maydeu, especialmente los últimos, reflexiones 
provocadoras acerca de la tradición y la creación, como El desguace de la tradición (2011), Continuidad y ruptura (2013) y La imaginación en la jaula (2015). Desde la teoría de los géneros, por su lado, escribe Rafael M. Mérida ensayos tan sugerentes como Transbarcelonas. Cultura, género y sexualidad en la España del siglo XX (2016).

Muy saludables (e intelectuales) han sido también las formas ensayísticas elegidas por Fernando Rodríguez de la Flor, toda vez que ha sabido demostrar su autoridad y su particular entender la literatura de los Siglos de Oro desde hondos análisis de los modos de producción simbólica, desde círculos interpretativos amplios y alejados de las tradicionales expoliciones de temas: así, La Península Metafísica: arte, literatura y pensamiento en la España de la Contrarreforma (1999), Barroco: representación e ideología en el mundo hispánico (1580-1680) (2002), Pasiones frías. Secreto y disimulación en el Barroco hispano (2005), Imago: cultura visual y figurativa del Barroco (2009), o Mundo simbólico: poética, política y teúrgia en el Barroco hispano (2012); pero la extrema sabiduría y el designio provocador, controvertido, siempre sugerente, de Rodríguez de la Flor puede detectarse también en ensayos de calidad insoslayable como Biblioclasmo: una historia perversa de la literatura (2004) o Contra (post)modernos. Tres lecturas intempestivas (Disidencia, Provincia, Carencia), Miguel Espinosa, Claudio Rodríguez, Antonio Gamoneda (2013) y en el excelente libro, escrito junto a Daniel Escandell, El gabinete de Fausto. "Teatros» de la escritura y la lectura a un lado y otro de la frontera digital (2014). A un discípulo de Rodríguez de la Flor, Germán Labrador, debemos uno de los ensayos filológicos de última hora que muestra el necesario atrevimiento para renovar el género: Letras arrebatadas: poesía y química en la Transición española (2009); a otro joven doctor en la diáspora yanqui, Juan Herrero-Senés, el clarividente Mensajeros de un tiempo nuevo. Modernidad y nihilismo en la literatura de vanguardia (2014), mientras que también es joven doctor en Filología Hispánica el escritor Jordi Amat, quien vive el ensayo (filológico, histórico, biográfico...) como territorio natural de una escritura brillante: no fue casualidad que lograse el premio de ensayo Casa de América con el libro Las voces del diálogo. Poesía y política en el medio siglo (2007), ni el Comillas de 2016 gracias al excelente La primavera de Múnich. Esperanza y fracaso de una transición democrática (2016); entre ellos, otro no menos fascinante, de interpretación de toda una historia intelectual, como es El Ilarg procès. Cultura i Política a la Catalunya contemporània (1937-2014), editado en 2015. 
Resulta esperanzadora esta vigencia del ensayo, y del filológico en particular, cuando las condiciones culturales para la creación y difusión, no solo del género sino del libro en general, son bastante adversas; o por lo menos así, hostiles, consideramos la mengua en número tanto de alumnos como de profesores (jubilaciones, amortizaciones, diáspora de jóvenes promesas en universidades extranjeras...) en los departamentos de Filología Española o de Teoría de la Literatura, el cierre paulatino, imparable, de librerías desde 1999, la disminución del nivel educativo de las sucesivas generaciones de estudiantes (de lectores, a la postre, en el futuro de corto a largo plazo) producto de las sucesivas leyes educativas... Pero persisten las voces que ensayan quizá por la vivencia urgente y comprometida de nuevos entusiasmos nacidos de un escenario de crisis generalizada. Es de celebrar que haya polémicas por la percepción distinta de procesos históricos y culturales, como la suscitada por la publicación del libro de Jordi Llovet antaño ganador del VI Premio de Ensayo Anagrama con Esquizosemia— Adiós a la Universidad. El eclipse de las Humanidades (2011), texto que responde a una atmósfera de desengaño gremial y generacional donde también ha de situarse (pero con tesis bien distintas de las de Llovet) el ensayo de Jordi Gracia El intelectual melancólico. Un panfleto (2011). Curiosamente, es estrictamente coetánea a esta polémica la aparición de los nueve volúmenes de la última Historia de la Literatura Española, la dirigida por José-Carlos Mainer para la editorial Crítica. Allí, el ensayo ha encontrado al fin digno acomodo en la narración de la historia literaria española; y, lo que es más importante, no solo la acompaña o se integra en su relato, sino que el modo ensayo fue una petición de principio aconsejable para la escritura de los diferentes capítulos y tomos (a cargo de Juan Manuel Cacho, María Jesús Lacarra, Jorge García López, Gonzalo Pontón Gijón, Eugenia Fosalba Vela, Pedro Ruiz Pérez, María Dolores Albiac, Cecilio Alonso, José-Carlos Mainer, Jordi Gracia, Domingo Ródenas, José María Pozuelo Yvancos y Fernando Cabo Aseguinolaza). Y como resultado, hubo de aparecer en las librerías nada menos que un nuevo formato para ese subgénero tradicionalmente tan poco desatado como ha sido el del manual de Historia de la Literatura:

\footnotetext{
(...) sin duda, este nuevo esfuerzo de conocimiento tiene un destinatario intelectual que se define cada vez más claramente. Las obras de la naturaleza de la nuestra, que caben en la amplia noción de «ensayo universitario», ya no tienen hoy como destino exclusivo las aulas, donde las
} 


\begin{abstract}
cosas se convierten a menudo en repertorio acumulativo de informaciones, sino que se dirigen a satisfacer el interés de un público que quiere ir más allá de la divulgación al uso y que busca panoramas estimulantes, críticos y no cerrados. Seguramente los géneros expositivos adecuados también han cambiado, a tenor de esta exigencia, y se vuelve al noble arte del ensayo, tras años de descalificación académica (la peor condena de una tesis doctoral vino a ser, y para algunos popes obtusos sigue siendo, la imputación de «ensayismo») (...) De entrada, hemos renunciado a la presentación escolar convencional, como se advertirá en el armazón mismo de capítulos y párrafos, que no es rígida y presuntamente didáctica sino más mullida y laxa. Como arriba se indicaba, se ha preferido invocar el ritmo del ensayo, al menos como propuesta de trabajo (Mainer 2010-2013:IX-XI)
\end{abstract}

Sí, ciertamente, el género del ensayo filológico español, por fin titulado como noble arte por su ejecutoria rica y fecunda en variados modelos, tiene el futuro asegurado: mientras haya voluntad de probar, de ensayar, mientras existan voces autorizadas con el atrevimiento de escribir desde una libertad rigurosa.

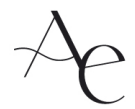

\title{
Bibliografía
}

Ara Torralba, Juan Carlos: «De Ayala a Baroja: Mainer o la renovación de la historiografía literaria española contemporánea. Una bibliografía (1965-2012)», Anales de la Literatura Española Contemporánea, 38, 1-2 (2013), pp. 7-44.

Arenas, María Elena: Hacia una teoría general del ensayo. Construcción del texto ensayístico. Cuenca: Ediciones de la Universidad de Castilla-La Mancha, 1997.

CARNERO, Guillermo: Las armas abisinias. Ensayos sobre literatura y arte del siglo XX. Barcelona: Ánthropos, 1989.

Cervera, Vicente, Belén Hernández y María Dolores Adsuar (eds.): El ensayo como género literario. Murcia: Universidad de Murcia, 2005.

García CASAnOva, Francisco: El ensayo entre la filosofía y la literatura. Granada: Comares, 2002. Gracia, Jordi: El ensayo español. 5. Los contemporáneos. Barcelona, Crítica, 1996. 
Gracia, Jordi: La resistencia silenciosa. Fascismo y cultura en España. Barcelona: Anagrama, 2004.

Gracia, Jordi, y Domingo Ródenas (eds.): El ensayo español. Siglo XX. Barcelona: Crítica, 2009.

Gracia, Jordi, y Domingo Ródenas (eds.): Pensar por ensayos en la España del siglo XX. Barcelona: Universitat Autònoma de Barcelona, 2015a.

Gracia, Jordi, y Domingo Ródenas (eds.): Ondulaciones. El ensayo literario en la España del siglo XX. Madrid: Iberoamericana. Vervuert, 2015b.

MAINer, José-Carlos: La Edad de Plata (1902-1931). Ensayo de interpretación de un proceso cultural. Barcelona: LosLibrosDe LaFrontera, 1975.

MaIner, José-Carlos: «Apuntes junto al ensayo», en Jesús Gómez (ed.): El ensayo español. 1. Los orígenes: siglos XV a XVII. Barcelona: Crítica, 1996, pp. 7-33.

MAIner, José-Carlos: La Filología en el purgatorio. Los estudios literarios en torno a 1950. Barcelona: Crítica, 2003.

MAINeR, José-Carlos: Tramas, libros, nombres. Para entender la literatura española, 1944-2000. Barcelona: Anagrama, 2005.

MAINER, José-Carlos: "Prólogo general a la Historia de la literatura española», en cada uno de los 9 volúmenes de José-Carlos Mainer (dir.): Historia de la literatura española. Barcelona: Crítica, 2010-2013, pp. VII-XVII.

Pozuelo Yvancos, José María: «La construcción de una tradición literaria nacional», en José María Pozuelo Yvancos (dir.): Las ideas literarias. 1214-2010, volumen 8 de la Historia de la Literatura Española dirigida por José-Carlos Mainer. Barcelona: Crítica, 2011, pp. 547-575.

Pozuelo Yvancos, José María: «El ensayo y la nueva poética narrativa», en Jordi Gracia y Domingo Ródenas (eds.): Ondulaciones. El ensayo literario en la España del siglo XX. Madrid: Iberoamericana. Vervuert, 2015, pp. 21-36.

Rıco, Francisco: Primera cuarentena y Tratado General de Literatura. Barcelona: El Festín de Esopo, 1982.

Rıco, Francisco: Textos y contextos. Estudios sobre la poesía española del siglo XV. Barcelona: Crítica, 1990.

Rico, Francisco: Estudios de literatura y otras cosas. Madrid: Destino, 2002.

Rıco, Francisco: Los discursos del gusto. Notas sobre clásicos y contemporáneos. Madrid: Destino, 2003.

Rıco, Francisco: En torno al error. Copistas, tipógrafos, filologías. Barcelona: Crítica, 2004. 
RóDENAS, Domingo: Travesías vanguardistas: ensayos sobre la prosa del Arte Nuevo. Madrid: Devenir, 2009.

TejADA, Ricardo, «El ensayo: ventana sin par del exilio republicano español», en Antolín Sánchez y Fernando Hermida (coords.): Pensamiento exiliado español. El legado filosófico del 39 y su dimensión iberoamericana. Madrid: Biblioteca Nueva. CSIC, 2010, pp. 203-229.

YNDURÁlN, Domingo, «Desahogo teórico y casi doctrinal», prólogo a Análisis formal de la poesía de Espronceda. Madrid: Taurus, 1971, pp. 15-19. 